\title{
The OTTOMAN PRACTICES of the KANUN of DUKAGJINI: The METHOD of CIBAL
}

\section{Ramazan BALCI ${ }^{*}$}

\begin{abstract}
The existence of a flexible structure changing according to local, political and geographical conditions in the Ottoman administrative system has been long known. This flexible structure which mostly appears in remote areas from center caused some problems in the works of strengthening the central administration which were carried out after the Tanzimat reforms had been declared. The Method of Cibal applied on the mountainous parts of Shkodër, has been handled as a sample of practice. The Method of Cibal has been based on the Kanun of Lekë Dukagjini which builds the historical identity of the region. The Code of Cibal Method is going to be broadcasted for the first time with this paper. The perspective of the political administration for this practice and works of repealing have been approached in the light of first hand sources.
\end{abstract}

Keywords: The Method of Cibal, The Kanun of Lekë Dukagjini, Shkodër Cibali, The Albanian traditions

\section{DUKAKINN KANUNLARININ OSMANLI UYGULAMASI: CİBAL USULÜ}

\begin{abstract}
ÖZ
Osmanlı idari sisteminde yerel, siyasi ve coğrafi şartlara göre değişen esnek bir yapının varlı̆̆ 1 öteden beri bilinmektedir. Daha çok merkezden uzak bölgelerde ortaya çıkan bu esnek yapı Tanzimat'ın ilanından sonra yürütülen merkezî idarenin güçlendirilmesi çalışmalarında bir takım sorunlara yol açmıştır. Örnek bir uygulama olarak İşkodra'nın dağlık kesimlerinde uygulanan Cibal Usulü ele alınmıştır. Cibal Usulü bölgenin tarihsel kimliğini inşa eden Lek Dukakin Kanunlarına dayanmaktadır. Bu makale ile Cibal Usulü kanunnamesi ilk kez neşredilmiş olacaktır. Siyasi idarenin bu uygulamaya bakış açısı ve kaldırılma çalışmaları birinci el kaynaklar ışığında ele alınmıştır.
\end{abstract}

Anahtar kelimeler: Cibal Usulü, Lek Dukakin Kanunları, İşkodra Cibali, Arnavut gelenekleri

\section{Introduction}

The administrative system of the Ottoman State shows a consonant structuring with its geographical condition and ethnicity. Whereas a long-established strict centralist dominion existed in the lands forming the main body of the state, there was a more flexible structure in the remote regions from the center. The works which point out this situation highlight the existence of privileged provinces. "There was a centralist structure based on deconcentrating in one part of the State; and there

\footnotetext{
*Yrd. Doç. Dr., İstanbul Üniversitesi, Türkiyat Araştırmaları Enstitüsü, ramazanblc@ gmail.com.
} 
were privileged provinces with decentralized specialties in the other part of it. It is possible to mention about a political and sometimes administrative decentralization for the privileged provinces." The privileged provinces which achieved to survive until the end of the state, had very different positions and specialties from each other. In the ends of this century, the political autarchies of Crete, Lebanon, Tunisia and Eastern Rumelia were close to the Egyptian and Samian administrative autarchies; and Bulgaria nearly had an independent state administration. ${ }^{2}$

While the first article of the Ottoman basic laws dated to 1876, describes the Ottoman State as "The Ottoman State is an indivisible integrity with its properties, lands in the Asian and European continents and privileged states in administration." it states the existence of the privileged provinces, and it regulates the sultan's rights according to this. Also in the $7^{\text {th }}$ article it is also explained: "Assignment and appointment in the states with administrative prerogative, have been under the authority of the sultan in accordance with the conditions of privilege." These articles express that the privileged provinces are not colonies and each other will be governed with a different status. ${ }^{3}$

On the other hand, it has been known that it is given broad authorities which can be sort of a special status, to the local chiefs in some small units of remote mountainous parts from the center. In Eastern Anatolia, there are some administrative unities called as "maktu'ul- kadem and merfu'ul kalem" that is any officer that have not been appointed from the center and never taken in inventory (such as tax and population). According to the imperial orders given to them in the periods of Selim I and Suleiman I, administration was descended from father to son, and they had no responsibilities except a determined annual fixed tax and joining the army with some members during a war. ${ }^{4}$

Unlike the existence of different administrative regions, "the millet system" which were applied for non-Muslims, also caused to appear different cultural structures in long centuries."Non-Muslim elements administrate themselves with the community parliament and in this way, the condition of a uniformity subjected to be seen in a more or less time, appears among the individuals living in the social committee. Their relationship with the dominant millet arises in paying tax; heads of the board of alderman that they select among themselves, carry out this."

This situation which does not produce too much problem in the classical period, will cause serious problems with the works of centralization after the Tanzimat reforms. Especially in the modern period in which nationalist movements of idea and national state mentality develop, the Ottoman State will have difficulties in preserving territorial integrity.

In this paper, the Method of Cibal, a nice sample for the aforementioned problems, which was applied to the mountainous parts of Shkodër, is going to be addressed.

\footnotetext{
${ }^{1}$ Ekrem Buğra Ekinci, "Osmanlı İdaresinde Adem-i Merkeziyet ve İmtiyazlı Eyâletler", Türk Hukuk Tarihi Araştırmaları, No. 6, Y: 2008 (Fall), p. 7-84. , p. 5.

${ }^{2}$ Stefanos Yerasimos, Azgelişmişlik Sürecinde Türkiye, (Tr. Babür Kuzucu,) vol. I, İstanbul 1987, p.190191.

${ }^{3}$ Ekinci, p. 25

${ }^{4}$ Ramazan Balcı, Osmanlı'nın Doğu Siyaseti, Yitik Hazine, İstanbul 2010, p. 30-90

${ }^{5}$ Mustafa Şeref, Hukuk-ı İdare-i Vilâyât, Derseadet 1329, p. 40.
} 
Albania was generally governed by the strong families of the region till the 1830 's. In Skopje, the hereditary power of the Yanya pashas was continuing almost without any interruption. The subject matter in this region was not only weak effect of the centralized administration, but at the same time the superior existence of the autochthonous laws called as the Kanun of Lekë Dukagjini, than the whole authority. ${ }^{6}$

The works of centralization after the Tanzimat reforms, met with difficulties in the regions with confidential status. After the reforms in the part of Cibal of Shkodër had encountered with armed struggle, "the Method of Cibal" with its official name was put into practice in accordance with the structure of the region. The Method of Cibal was essentially based on the Kanun of Lekë Dukagjini. ${ }^{7}$

The Kanun of Lekë Dukagjini had continued to survive as a national law which had never lost its effectiveness among Albanians, since the $11^{\text {th }}$ century. The works on this subject, evaluate this code as a part of the oral folk tradition, and especially draw attention to its cultural aspect. ${ }^{8}$ The works of Durham ${ }^{9}$, an English traveler who carried out some sociological searches and Fransisken Shtjefan Gjeçov ${ }^{10}$ are also the works gathered together from the folk's discourses in general custom style. The practice that the Ottoman State put into force with the name of the Method of Cibal, did not appear in both works.

\footnotetext{
6 "The subject law was a system applied on the central provinces connected to Shkoder, the Region of Malesiathe provinces of Mirdita and Puka, Maliya ofLesh and sub-districts of Zadrime, the Tuz district's Hot and Gruda tribes" İlkay Erken, Isşkodra Vilayetinin İdari Ve Sosyal Yapısı (1876-1912), Ondokuz May1s University. Department of History, Master Thesis, SAMSUN 2014, p. 427. Cibal-i mülhaka was five cibal until1284 Z 3 but in this date, the cibal of Posteriba was given to the administration of the Cibal Commission by assigning a head of alderman board thereBOA. İ. ŞD 1/7.

The year of 1892 "According to the Shkoder Province Annual, Great Malesia was divided into ten mountains (cibal) in the administrative manner. The total population was 40.000. see. Hasan Bello, Osmanlı Ve Arnavut Kaynaklarına Göre Arnavutluk'ta 1911 Malisörler İsyanı, the university of Mimar Sinan Fine Arts. Master Thesis, İstanbul 2009, p. 2.

${ }^{7}$ According to the collective memory, Leke Dukagjin was a member of the family Dukagjin who lived in the $15^{\text {th }}$ century (Lek or Leke Aleksandros is Albanian of his name). Traditionally, this person has been accepted as Leke Dukagjin III (1410-31) olduğu; in fact, an Albanian writer Fan Noli, considers that he was Pal Dukagjin (01:1446). Edith Durham's preference is Lek Dukangjin II who ruled between 14441459. (Zef Ahmeti, "The Criminal Law in the "Kanun of Lekë Dukagjini"',,(Tr. Bertan ARIN and Dr Gülsen ALTUNTAŞ) (http://www.shkoder.net/en/kanun_en.htm. ET:01.06.2014)

${ }^{8}$ In a very late period, Bedi Nuri asserts that the code was not written. "Cibal kanunu hakkında söylediğimiz bu ahkamın sıhhat ve mer'iyyet-namesi iddia olunamaz. Çünki bu kavanin mektûb olmadıkları için ceza-yı nakdî ve şuhud miktarı cebelden cebele tehallüf eder." Bedi Nuri, "Müsahabe-i İçtimaiyye, Arnavutluk Teşkilat-1 İçtimaisi: Cibal Kanunu”, Şehbal, nr. 64, s. 305, 26 Eylül 1328; The approach of the official outlook of counting the law as custom for the Method of Cibal stated in many documents due to being in force with the state's regulation and permission, is remarkable. Taking the work of Vaha Pasha about Albania from the library of Yıldız is about this approach. BOA. BEO. 4090/306747, 1330 L 18

${ }^{9}$ Edith Durham, (1928), Some tribal origins, laws and customs of the Balkans, Illustrated by the author. London: Allen - Unwin, London 1979. 1-318 S.

${ }^{10}$ These laws have firstly been gathered together by Kosovan Fransisken Shtjefén Gjegjovi and Albanian Fransisken started to publish in the magazine of "Hylli i Drités" in 1913. After Gjegjovi had been killed by Serbians in 14.10.1929, it was published as a book with a name of "Kanuni i Leke Dukagjinit". see. Kanuni i Lekë Dukagjinit - The Code of Lekë Dukagjini, Albanian text collected and arranged by Shtjefën Gjeçov ; translated, with an introduction by Leonard Fox. New York 1989
} 
Cevdet Pasha who went to the region for improvement works in 1865 , briefly mentions about the Kanun of Dukagjini in his collection of biographies about the subject: "There is a single law with particular articles among Malisors living in Shkoder." According to Pasha, the clergy and Ottoman government have worked on changing these laws. However the public order was disturbed since Malisors did not obey the local laws. Pasha allowed for an instruction which was prepared in 1275, for the restitution of the public order. The instruction consisted of a few article regulating the penalties of homicide and physical injury coming after blood revenges had been made peace. Pasha asserts that the cibal people had monotonous laws, but they lost their importance due to the works of the government. However he did not mention about these laws. ${ }^{11}$

As parallel to the increasing problems in the region, the works on Albania have also increased. According to my detections, the manuscript named Arnavutluk ve Arnavutlarin Ahvaline Dair Tarih (History about Albania and Albanian Circumstances) of Ali Galip Bey, the head of the education organization, is the first work which mentions about the Kanun of Dukagjini among the Ottoman laws.

The book, on its $4^{\text {th }}$ chapter, allowed for the instruction regulating the penalties of homicide and physical injury with 21 articles which were announced with the name of the Kanun of Dukagjini in 1288. Moreover, he added the article which was written by Halil Rifat Pasha about the Kanun of Dukagjini to Monastery Annual (Manastır Salnamesi) ${ }^{12}$.

Another work about this subject is Vasa Efendi's book named as Albania and Albanians (Arnavutluk ve Arnavutlar). Vasa Efendi allows his work's $11^{\text {th }}$ chapter for traditions among Albanians and tries to explain the reasons of the improvements' failure. ${ }^{13}$ Some sources mention about Giritli Sirrı Pasha's work named the Kanun of Lekë Dukagjini, however the book has not been reached yet.

Many works about the subject have missed that the Ottoman State included the Kanun of Lekë Dukagjini into the juridical and administrative system. That the Kanun of Lekë Dukagjini has not been taken place among the selected documents about Albania that Ottoman Archives of Prime Ministry has published, is an important deficiency. ${ }^{14}$ Erken who summarizes the works of the Cibal Commission seen as an executive organ of the Method of Cibal practiced in the Ottoman system, should have not seen these laws. ${ }^{15}$ These laws have not been mentioned in an assertive work called as A Socio-economic Overview on the Ottoman Codex Belonged to the Lands of Albania (Arnavut Topraklarina Ait Osmanl Kanunnameleri Üzerine Sosyo Ekonomik Bir Bakış). ${ }^{16}$

\footnotetext{
${ }^{11}$ Cevdet Paşa, Tezakir 13-20, (Cavid Baysun) TTK. Ankara 1960. p. 206

${ }^{12}$ Belediye Yazmalları K 383,vrk. 27 b-40 b; the work is dateless. It might be said that it was presented to Sultan Abdul Hamid between 1290-1295 when its content is considered; Manastır Salnamesi (The Monastery Annual) 1305, s. 470-479 First Time

${ }^{13}$ Vasa Efendi, Arnavutluk ve Arnavutlar, İstanbul Mihran Matbaası 1298, p. 98-108

${ }^{14}$ Osmanlı Arşivi Belgelerinde Arnavutluk, Devlet Arşivleri Genel Müdürlüğü Osmanlı Arşivi Daire Başkanlığı, İstanbul 2008.

${ }^{15}$ Erken, a.g.e.

${ }^{16}$ Dritan Egro, Arnavut Topraklarına ait Osmanlı Kanunnameleri Üzerine Sosyo Ekonomik Bir Bakış, The University of Ankara. Master Thesis. Ankara 1997.
} 
Söylemez did not state one of the most important sources of Albanian nationalism in her doctoral thesis named Ittihat Terakki Dönemi Arnavut Muhalefeti ve Arnavut Ulusal Hareketi (Albanian Opposition and Albanian National Movement in the Period of Union and Progress). ${ }^{17}$ Lastly, the work of Bozbora who mentions about the cultural effect of the Kanun of Lekë Dukagjini, but not the existence of the practice, has to be indicated. ${ }^{18}$

The Ottoman administration, with this paper we have prepared to diffuse, firstly brought the Kanun of Lekë Dukagjini living as preconceived folk traditions among Albanians, into a law format and practiced in the region for a long time. ${ }^{19}$

\section{People of Cibal and Ottoman Administration}

Despite of the strict centralist administration in the Ottoman state, the law of cibal that cibal community of the state allowed to remain in force, based upon a historical rumor: when Murad Hüdavendigar conquered Kosovo and its vicinage, an Albanian came to the imperial tent and complained about his stolen sheep herd. By the time the khan had ordered to find the herd, the chiefs of cibal put forward that thief would be caught immediately in case of solving the problem according to the local laws.

They were given permission for this, and immediately the council of cibal gathered, and perpetrator was revealed. Sultan, who was very satisfied with this situation, commanded an imperial order including a privilege of resolving the cases in Albania in conformity with the local laws. ${ }^{20}$

Although it is hard to say something about trueness of this historical rumor, it will not be possible to understand what has done without indicating the effect of the Kanun of Dukagjini on the region. That the reaction Cibal people show against the practices the state wants to put in force in the period of innovation, attribute to only avoiding to give taxes and soldier, is to oversimplify the issue. That the law became identical with the local people, has been the subject of many researches. When it is evaluated from this point of view, it can be said that the Kanun of Dukagjini appeared from the geography and folk's soul that it developed in. In the areas lack of state's authority which will provide the justice, the order can only be provided by the existence of the right of protecting individuals' honor. Ahmeti indicates this aspect of the law.

"On the basis of the law, there is primarily individual's honor. After that equality among individuals becomes. A third principle of them comes out: freedom of acting according to own honor concerns in

\footnotetext{
${ }^{17}$ Banu İşlet Söylemez, İttihat Terakki Dönemi Arnavut Muhalefeti ve Arnavut Ulusal Hareketi, İstanbul 2004

${ }^{18}$ Nuray Bozbora, Osmanlı Yönetiminde Arnavutlar ve Arnavut Ulusçuluğu, Boyut Kitapları, İstanbul 1997

${ }^{19}$ Kanun resmî taraflarca sahiplenilmese de DahiliyeNezaretince hazırlanan bir mazbatada kanunun "geçici kanun layihası "olarak hazırlandığı anlaşılmaktadır. İfade şu şekildedir. "Adat ve muamelat-1 mahalliyeye evfak olan ahkam ve icraata dair tanzim olunan mevadd-1 muvakkata-i kanuniye layihası münderecatının icab-1 hal ve maslahata muvafik ve o havalice te'sirat-1 haseneyi mucip bulunmuş olacağıı"BOA. MV. 226 /113, 1330 S. 22/ 1327 KS. 29

${ }^{20}$ Bedi Nuri, "Müsahabe-i İçtimaiyye, Arnavutluk Teşkilat-1 İçtimaisi: Cibal Kanunu”, Şehbal, nr. 64, p. 305, 26 September 1328
} 
legal borders and without any other one's dominion. The forth principle is parole of honor which means bese (besa) and this creates a situation based upon steady sense of trust." ${ }^{21}$

When Boman and Krasniqi who suggest that the law symbolizes the Albanians' cultural identities in various ways, say 'the Kanun of Lekë Dukagjini is a good sample on institutionalizing the culture", they draw attention that the institutions control human behaviors by creating models which canalize human motions, with the existence of these laws. ${ }^{22}$ On the other hand, it has been indicated that the Kanun of Lekë Dukagjini coalesced a tribal society which had been indigenous and of which social vicinity had never changed in long centuries, in socio-cultural manner. $^{23}$

Dragovaja who compares the Code of Dukagjini with the laws of Dagestan living in similar geographical conditions, has detected that even religious dogma expected to be effective on human behaviors, stayed in the background of the Code of Dukagjini. According to the research, the effect of the Islamic sharia on the Code of Dukagjini is 30-35 \% less than its effect on the laws of Dagestan. While individuals have equal rights in society in the Code of Dukagjini, the socioeconomic condition of an individual is determinative in Dagestan. In the Code of Dukagjini, women do not have a right of succession and also members of family do not have rights of possession. On the other hand, Dagestan has a reverse situation. ${ }^{24}$

Saygilı's detections transmitting from Durham who carried out the first sociological researches in the region, reflect the same aspects. "The Kanun of Lekë Dukagjini is obeyed rather than the Prophet Moses' ten commandments among Albanians. Neither the law of church nor the sharia could downgraded the Kanun of Lekë Dukagjini." 25 It has to be accepted that the works against abolishing such an integrated social fact with people will get into the huge difficulties.

As it had been expected, the people of Cibal who did not give any military service except wars due to their privileged status under the Ottoman administration and paid annual exaction tax as a lump-sum, argued against the regulations for strengthening the central administration. New regulations forced them to leave the Kanun of Lekë Dukagjini which was a traditional law and judging system, besides compulsory military service and responsibilities of taxes. The growth of the groups

\footnotetext{
${ }^{21}$ Zef Ahmeti, "The Criminal Law in the Kanun of Lekë Dukagjini"',,(Tr. Bertan ARIN and Dr Gülsen ALTUNTAŞ) (http://www.shkoder.net/en/kanun_en.htm. ET:01.06.2014)

${ }^{22}$ Sofia Boman and Njomza Krasniqi, The Kanun of leke Dukadjini Among Kosova Albanios in Sweden, Malmö University, Department of Global Political Studies, Master's Programme, 2012. P. 45-46

${ }^{23}$ A. Yılmaz Soyyer: Osmanlı Devleti'nde İlk Alan Araştırması, @kanalkultur İnsan ve Kültüre Dair..29 July 2013 Monday

${ }^{24}$ Muharem Dragovaja, A Comparatıve Study Of The Customary Laws Of Mountain Communitles In Albanıa And Dagestan, Tirana 1996

${ }^{25}$ Hasip Saygılı, "20. Yüzyılın Başlangıcından Günümüze Arnavutlarda Osmanlı ve Türkiye Algısı", Bilge Strateji, Vol 6, No 10, Fall 2014 p. 38; For Külçe's detections in the same way see. "Every Albanian knows well the existence of such alawfrom the all manners of necessity and need and even belief. Especiallythis order adopted by Malisyave Mirditans did not even diminished far from never losing its importance and value... Yes, whereas there was not any Albanian who did not complain about this wrong custom, there was also no one who did not see getting out of its orders such as feuding, as dishonor... ”Süleyman Külçe, Osmanlı Tarihinde Arnavutluk, İzmir 1944, p.373
} 
that lost their old reputation with abolishing the old manorial system, and privileged status of the other minorities with the Edict of Reformation (Islahat Ferman1) caused serious issues in the region. Albanians of Cibal did not hesitated to resist in violence to protect the privileges that they had taken from the Ottoman Sultans. ${ }^{26}$ Another issue which increased the disorder in the region, was the practices of the civil servants of the Tanzimat reforms. According to Sava Efendi "Albania has become in complicated situation with incompatible moves due to the subject officers' greed of illegally collecting possessions and new useless administrative inventions since the officers sent for securing uniformity in the subject region, removed the old laws and were not able to replace the new administrative method and new laws. ,27

In 1847 and 1856, after the full-scaled provincial rebellions, a new method of Cibal protecting the old privileges of the Cibal Albanians, was put into practice. The detections about the date on which the law was put into practice, are given below:

In a report which is sent to the Grand Vizierate by an inspection officer, Ismail Hakk1 who went to the region with the request of the grand vizier, it is stated that the regulations about the Method of Cibal was prepared in $1275 / 1858{ }^{28}$ A copy of the regulation about the Method of Cibal exists in the Ottoman Archives (BOA. A. DVN. MKL number 75/4.) It is a booklet bound with 8 gilded mottling cover. However there is not any date on the document. The year of $1285 / 1868$ has been given as an approximate date. ${ }^{29}$ This estimation's incorrectness has been unearthed with the report which was written by Ismail Hakkı. In the instruction sent by Cevdet Pasha who was in the region for the works of improvements in 1281/1865, for the Malisors, that he wants the provisions of burning house and confiscation in the Method of Cibal not to be applied, shows that the law had been put into force before this date. ${ }^{30}$

The instruction of the Method of Cibal which was being prepared to diffuse, was taken from the correspondence of Mehmed Edip, governor of Shkoder, in January 6, 1897. The governor stated that he transmitted this instruction from the

\footnotetext{
${ }^{26}$ Bozbora, s. 319

${ }^{27}$ Sava Efendi. p. 113 (For the movements of revolt and discipline in the Eastern Anatolia after the Tanzimat reforms see. Ramazan Balcı, Osmanlının Doğu Siyaseti, Kaynak Yay. İstanbul )

${ }^{28}$ BOA. MLV. 977/25 (08/Ş /1280); (Some attractive information exist in this report of İsmail Hakk1. As it has comprehended from the document, he is annoyed to the heads of board of alderman in the Grand Vizier Cibal Committee. He plans constituting the commission from standard-bearers instead of them. However İsmail Hakk1 announced that standard-bearers were not enough in number as the heads of alderman board were. İsmal Hakk1 offers for the instruction to be practiced for a while upon the demands of the heads ofCibal without the information of the Ottoman Porte. In the response, it has been stated that the issue was sent toMeclis-i Valay-1 Ahkam-1 Adliye. It has been understood that the instruction was temporary accepted. However then, there was no opportunity to abolish it.

${ }^{29}$ BOA. A. DVN. MKL 75/4

${ }^{30}$ Cevdet Paşa, p. 206; Engelhart who suggests that the Frenchesoffered the Method of Cibal, should be interfused the issue. The French offer he suggest that it was in 1890, is about detecting the head and members of the Cibal commission by voting. With the objection of Russsians, the offer was not accepted. Here, suggesting that this offer was brought into life by the Ottoman government as the Method of Cibal, leads to confusion. (Engelhardt, p. 319 vd.) The offer Engelhart mentions, came out after that the Ottoman State had undertaken the responsibilities of making proper regulations to the local needs in the states of Rumelia and forming private commissions from the local members in the $23^{\text {rd }}$ article of the Berlin treaty in the date of July 1878.But the Method of Cibal was put into practice before this date. see. Nihat Erim, Devletlerarası Hukuku ve Siyasi Tarih Metinleri, Ankara 1953, p. 413 and 423.
} 
Record of the Province Administration (İdare-i Vilayet Ceridesi). When the beginning of the broadcast life of the Shkoder Province Newspaper (İsskodra Vilayet Gazetesi) in 1868 is considered, the probability of the instruction's operativeness before this date becomes strong. ${ }^{31}$

On the other hand, an Albanian historian Ulqini who gives significant information about the foundation of the Commission of Cibal, suggests this date as 1855- 1856. "'The Cibali Commission' which was delegated the administrative, judiciary and military authorities in Shkoder to dominate the flags of Malesia and Dukagjini, and was responsible for gradually eliminating the administrations of these mountainous areas, was founded. The commission was based on the laws of the Ottoman administration",32

According the sources which have been mentioned, it has been understood that the Method of Cibal was put in practice between the years of 1855-58. If the style of the instruction's text is considered, it is seen that it is written in a serious legalese and logic beyond a randomly written text. This text should have been prepared in a council of the Tanzimat reforms. In case of scanning the records of the period, it is seen possible to reach the discussions about the law. following: ${ }^{33}$

The regulated issues with the Method of Cibal have been given in

The punishments which will be given to the ones who have killed a person that they reconciled with, or another agent in the administrative system, the punishments that will be given to the ones who have hidden the criminals, the procedures in case of the murderer's commitment to the state or his escape, the peace price that the murderer must give to the relatives of the victim, the penalties which will be given to the ones who have joined the army in war and the ones who have decamped, the punishments to the ones who do not obey the orders given by the state, the punishments to the ones who do not join to the councils which must be gathered in the highlands with the governmental order, impossibility of litigation again about the decisions in the commissions of highlands...

The victim's inheritors' right of killing a member of the murderer's family, the punishments to the ones who have forcibly abduct a girl, the punishments to the ones who have killed a woman, the punishment to the ones who have damaged the agricultural neighborhoods, the punishments to the ones who have beaten a person and taken his weapon, the punishments to the ones who have forcibly taken one's possession, the punishments to the ones who have killed a victim with a gun and cut the victim's organs for insult, the attestation councils

\footnotetext{
${ }^{31}$ The provincial directory in the $2^{\text {nd }}$ November 1864 sentenced to assign agent of letter for the provinces and give the provincial printing houses in the future to the letter agents' administration. Shkoder Province Newspaper started its broadcast life in 1868. see. Uygur Kocabaşoğlu, Ali Birinci,"Osmanlı Vilayet Gazete ve Matbaaları Üzerine Gözlemler”, Kebikeç,No 2, 1995, p. 101-121

${ }^{32}$ Hasan Bello, Osmanlı Ve Arnavut Kaynaklarına Göre Arnavutluk'ta 1911 Malisörler Isyanı, the University of Mimar Sinan Fine Arts. Postgraduate Thesis, İstanbul 2009; Kahreman Ulqini, Bajraku ne organizimin e vjeter shoqeror (fundi I shek. XVII deri me 1912), Tirane 1991, p. 16.

${ }^{33}$ For full text of the Medhod of Cibal see Appendix 1.
} 
and provisions for being absolved from the accusation of murder, the punishments to the ones who have ransacked places such as house, dairy and fold, the punishment about the robberies in free lands, bringing witness to the oath council, the parliaments which will be regulated about the cases of debt, the punishments to the crimes which will be occurred in the gardens of mosques and churches, the regulation of the rights of succession, the punishments to a stranger who has married with an engaged woman, the punishments to the ones who have insulted to the heads of alderman community and heads of company in charge at commissions...

The cases will be settled in the commissions of Cibal and practiced in the supervision of the state. ${ }^{34}$

The missions of heads of company are announcing the orders of the state and commission of Cibal to the Cebel chief and people that they are belonged to, providing to tax gathering, and practicing the orders that the cebel chief will give, reporting the events to the state in written every day, and bringing the men who are looked for by the state and Cibal commission. They do not have the rights of interference to the decisions of the chiefs.

The missions of the chiefs are distributing the determined taxes to each house in the highlands they belong to, deciding about the cases that the commissions send them and practicing these decisions via executive officers.

There are 608 executive officers in the highlands ruled by the method of Cibal (there should be a different tribe in each highland). Their mission is practicing the decisions made by the Cebel chief and Cibal commission. Being an executive officers reverts to son from father likewise being a chief. ${ }^{35}$

\section{Cibal}

The Ottoman Practice of the Kanun of Lekë Dukagjini: the Method of

The Ottoman Cibal Method aims to connect different traditional practices continued in mountains and take them in the state's control. The administration of each uncultivated land (cebel) is in the hands of a company head who takes the authority from his family's power. The head of company dominates it with a council of the land's elites. The Ottoman practice gathered the heads of company of six lands cibal together in a council named as the Commission of Cibal in the center of the province. Every type of case about the people of Cibal would be discussed and concluded in this council. A head of the council and governorate clerk are assigned. Heads of company selected as members of the Cibal commission, inhabit in Shkoder and earn 300 piaster. $^{36}$ It will be suitable to draw attention other outstanding features of the law:

\footnotetext{
${ }^{34}$ For Commissions of Cibal see Appendix 2.

${ }^{35}$ BOA, Y. MTV. 149/81 VRK. 1-8 (BOA. A. DVN. MKL 75/4 number has a different copy of the document in the title of Cibal Usulü. There is not any date on it. The document has been approximately dated to 1285. It has been bound with 8 gilded mottling cover.)

${ }^{36}$ Es-Seyyid Mehmed İzzet, Osmanlı Arşivi Belgelerinde Arnavutluk, Devlet Arşivleri Genel Müdürlüğü, Osmanlı Arşivi Daire Başkanlğı, İstanbul 2008 p.203,13 April1880
} 
The decisions the commission made, are practiced by the kubar and heads of company in the provision of executer officer in the tribes. Collecting taxes and reaching the desires of people to the government will be carried out by the heads of the board of alderman in the same way.

In case the one who murders, runs away and hides, he/she will be deprived of any social right and justice with his/her family. The one who hide the murderer will be common to his/her crime.

When the homicide is committed, kubar and heads of company will move with the state's order and the punishments of the yielders will be given by the legal courts. The Kanun of Lekë Dukagjini will be put into force for the escapers.

As it has been seen in the punishments which have been practiced to the ones who do not go to the military areas they have been dispatched, the punishments are applied to the whole family, and in this way, its effect has been tried to be increased among the Albanians who are addicted to protect the family honor. The orders of the kubar and heads of the board of alderman will be accepted as a governmental order and in this way, the dependence of the tribes for the state will strengthen.

The $9^{\text {th }}$ article has accepted the famous blood revenge in the same way of the tradition. The right of a revenge of a victim person was not accepted after any punishment of a crime had been detected by the government. If a murderer insults the body of a person who is killed by him/her, the right of blood revenge doubles up.

As a claim of homicide is accepted with an oath, an accusation of homicide might be also rejected. It is assumed that an honorable person do not perjury. Moreover, the defendant will swear not by him/herself, but with six to twenty-four reliable people according to the significance of the crime. ${ }^{37}$

The law of inheritance was not confirmed by the Islamic orders, and possessions were given to the control of the closest male member to the family. The right of disengagement was not given to women who had created a certain connection such as engagement, contract and marriage.

An extra wage was taken for the Cibal Commission in any case. The precautions increasing the commission members' reputations, were taken. All precautions of reformation that the government had wanted to practice in the region, were desired to be carried out especially after the peace which had been provided with the payment of the diets of blood feud by the state. The announcement of this law was also after such a compromise. ${ }^{38}$

\section{Official Outlook to the Method of Cibal and the Efforts of Abolishing It}

It might be said that the official outlook to the method of Cibal which should be counted as a step back for the administration of Tanzimat reforms, was always negative. The absences of any name, sign and date in any of the documents about the law in the archive and the opinions appeared during the works of abolishing this law,

\footnotetext{
${ }^{37}$ One of the oddness in the Method of Cibal is to prove that the defendant is innocent besides the obligation of proving the complainant's claim. Nuri, Şehbal, p. 304

${ }^{38}$ For the works of the peace commission see. Adem Ölmez, "Osmanlı Devleti'nin Kosova'da Kan Davalarını Önleme Çalışmaları (1878-1912)”, Güney-Doğu Avrupa Araştırmaları Dergisi, 2009, p. 87104.
} 
have been full of the statements which show this negative perspective. ${ }^{39}$ The state watched for an opportunity to change the Method of Cibal which was entirely opposite to the soul of the Tanzimat reforms. Primarily an organization of a subdistrict, an organization of gendarme to provide security and criminal courts of peace should have been founded for this in the region. The reluctance of the Cibal chiefs for any cooperation with the government and their fond thoughts and disobedient behaviors were shown among the reasons of abolishing the Method of Cibal. Their providing benefits in various ways by using the ignorance of people, was making the issue harder. The absence of road avoided the usage of forest products for people and while the traditional moral fell into decay, stealing and robbery was increasing. ${ }^{40}$

The state founded the commissions of "musalaha-i dem" to reconcile the blood feuds due to the code of Dukagjini, and wanted to abolish the Method of Cibal by providing the mood for the benefits of the state. However the government had to take a step back on every strong reaction. One of the fist attempts carried out in the winter months of 1878-79. The tribes of Cibal thought that the traditional privileges were taken away, revolted again, and then Abdul Hamid II had to postpone the issue of collecting tax and soldier, and let the Albanian courts continue in the region of Kosovo. ${ }^{41}$

Sultan Abdul Hamid did not give up to follow the issue, and ordered to found a new township under the name of the township of Cibal by connecting miscellaneous sub-districts. ${ }^{42}$ The people of Cibal revolted again on the excuse of the tax rises, and the government settled the rebellion by forgiving the rebels and debts of tax. ${ }^{43}$ Any decision of reformation about Albania and Shkoder made the people of Cibal revote. During the reregulation of the sub-district community in the province of Shkoder in 1897, it was guaranteed that this reregulation would not be practiced in the highlands in the administration of the Method of Cibal. ${ }^{44}$

About the issue of abolishing the Method of Cibal, the unionist governments also undertook some enterprises however the approaches of the local people did not change. ${ }^{45}$ The matters that the governor and commander of Shkoder in that period, Hüseyin Vasfi pointed out, are quite remarkable in the manner of showing the official perspective: "The content of the code of Dukagjini is not generally proper to the civil law and methods. These laws include prisoning a man for a ten piaster debt until he pays, and prisoning all members of the family and all his relatives for the father's crime, confiscation of his possessions and cruel provisions and oppressions such as burning his house, and in a period in which the constitutional monarchy has been declared, condoning such a law is not absolutely permissible.

\footnotetext{
${ }^{39}$ For instance, the law of Dukagjini is described as "being in force from the ancient period but unsubstantial base..” in a document. BOA. İ. MMS. 48/2028, vrk.3.

${ }^{40}$ BOA. DH. ŞFR. 302/46 1-5; 9 February 1318

${ }^{41}$ Bozbora, p. 319

${ }^{42}$ BOA. Y. A. RES. 22 /9; 22 November 1883

${ }^{43}$ BOA. İ. DH. 953 /75381, 27/Ş /1302; BOA. ŞD. 311/9 ; 22 July 1886; 20/L /1303

${ }^{44}$ BOA. DH.TMIK.S. 5 /100, 07/Ş /1314; 25 January 1897

${ }^{45}$ Meşrutiyet dönemi Arnavut isyanları konusunda bilgi için bkz. Bilgin Çelik, Ittihatçılar ve Arnavutlar, II. Meşrutiyet Döneminde Arnavut Ulusçuluğu ve Arnavutluk Sorunu, Büke Yayınları, İstanbul 2004.
} 
Despite of this, any person against this law do not exist among the people of cibal. The reason is that the people stay away from education. It is the fact that they did not get a taste of the pleasure of justice and civilization. Unless the government or the commission of cibal provides justice, they take their revenges by themselves." 46

The related documents give priority to the necessity of completing the organization of township for quashing the law. ${ }^{47}$ However there was not any attempt about this issue. Despite the month December of 1910 had come, it could not be possible to pursue the people of cibal. Especially the malisors of Kelmend, Hot, Gruda and Kastrati rejected to give tax and soldier. ${ }^{48}$ Even though the government had a decision of practicing customary administration and surging soldiers when it was needed, the private situation of the region did not allow a more advanced precaution. Apparently, the organization of township was completed, however the foundation of the security courts and sending magistrates were adjourned. Completing the organization of gendarme was shown as the reason of this. ${ }^{49}$

The observation of Minister of Justice in the same date shows that the government did not find a solution to solve this problem. "A law review called as the Code of Dukagjini and known as longstanding famous, has been practiced. It has been seen indispensable according to the current conditions that the new laws which will be regulated for that region, must be close to the old ones in a certain extent."50

The Council of Deputies (Meclis-i Vükela) started to rework on the improvement of Shkoder in the March of 1912 and tried to determine the basics of the improvements by taking all supervisors' opinions. Prepared proposal namely Musalaha-i dem layihasi (the articles regulated for reconciling the ones who have blood feuds among them) and practicing it in the area was not accepted by Ministry of Justice and the highlanders (cibal-i mülhaka) ruled by the Method of Cibal, the tribes living in mountains. ${ }^{51}$

The government continued to argue the issue and gave these expressions in the one of the last decisions in the date of May1912. "The law and penalty cases which have still been in practice, and the Code of Dukagjini of which purviews have not been written, include traditions and practices which have not been proper to the Basic Ottoman Laws. Thus, a new law bill will be regulated in accordance with the morality and nature of people and congruently to the state's judiciary laws to put the law into practice, a township would be founded in the bazaar area of Shkoder, Çarş11 kebir province. ${ }^{52}$ It has been understood from these expressions that the decisions about founding a township organization before did not put into practice. On the

\footnotetext{
${ }^{46}$ BOA. BEO. 3842/ 288080 (Hijri) 4/M /132

${ }^{47}$ BOA. BEO. 3832/287329, 03/Z /1328

${ }^{48}$ BOA. BEO $3856 / 289129$ (Hijri) 12/S /1329

${ }^{49}$ BOA. BEO. 3842 /288080 (Hijri) 04/M /1329

${ }^{50}$ BOA. BEO. 4087/ 306524

${ }^{51}$ Also it strengthen the sense of religion and the Islamic order and besides this, there is "a propaganda committee composed of a doctor and a teacher" to send for working for the development of the Albanian idea and feelings to struggle with the Latinism and Slavism movements MV: 162/63, 1330 Ra 20 / 26 February 1327, (lef 5)

${ }^{52}$ BOA. MV. 164/68, 1330 Ca 25 / 29 April 1328
} 
other hand, the government suggests to find a common way instead of directly abolishing the Code of Dukagjini.

Any record about the practices of these laws was not encountered when months were left over the beginning the Balkan wars. Moreover no clear expression about the law being abolished, did not take part in the reformation programs of Shkoder. As it has been known, Shkoder would be lost in the $13^{\text {th }}$ April of 1913.

\section{Conclusion}

This paper has revealed The Kanun of Lekë Dukagjini seen among the traditional cultural values, with the style of appearing in the Ottoman administration and law system. It is outstanding that the code was included into the Ottoman law system among the Tanzimat reforms. After the Ottoman basic law had been declared, the continuation of the practice including the contradictious provisions against both the Islamic bases and the new laws, should be completely about the strategic conditions that the region has.

Considering the evaluations about the law in different aspects, is possible. There is no doubt that we face with a very essential experience when it is looked from the perspective of the Ottoman State. The fertility and flexibility of the state's mind manifest itself in this experience. The state's experience achieved to produce new solutions in the most difficult conditions - especially in the manners of nature factors and human nature-, and succeed in controlling the region all the way by overcoming the political and economic crises.

The Method of Cibal with the name in Ottoman practice, controlled the tribes' traditional practices completely out of the state's control, in a measure. Informing the governorate in every step, and judging the case in the legal courts after the suspect had been given to the state's forces, gave an opportunity to limit the tradition with only escapers.

Despite of the fact that the code of Dukagjini served to the national identity of Albania, it gradually became the source of many problems for the region and it constituted one of the biggest obstacles for the social development. The practice of human values developing with the modern age, constituted a serious obstacle for the economic improvements and placing the modern state institutions. The administrative class who wanted to protect their own benefits, objected to every kind of change and prevented the people's connection with the government and brought people into poverty and ignorance since they limited the opportunities of manufacture and marketing. For instance, the blood feuds legitimated by the law, ruined the social life and the male population of a city became unable to go out from their houses. According to a scientific assumption, the $19 \%$ of the male deaths through the end of the Ottoman period is caused by blood feuds. ${ }^{53}$

The strategic importance of the geography of the northern tribes that the Ottoman manorial system could not reach, was essential rather than economic significance. The Ottoman State respected the customs and beliefs of the rough and short-tempered local tribes to keep the region. A kind of a private status was given

\footnotetext{
${ }^{53}$ Saygılı, p. 38; for the ruin caused by the blood feuds also see. Çelik, "Geleneksel Yapı İle Modernite Arasındaki Gerilime Bir Örnek: Arnavutluk’ta Kan Davaları ve II. Meşrutiyet Döneminde Soruna Çözüm Arayışları", Studies of Ottoman Domain, Vol: 4 No:7 August 2014. S 18-41
} 
with the conditions of giving an annual tribute and joining into army during war. The usage of these tribes for the military purposes such as providing the border security of the Empire was a satisfied solution for both sides. ${ }^{54}$

\section{APPENDIX 1}

\section{Cibal Usulü}

Birinci madde:

Bâ-irade-i seniyye-i hazret-i padişahî vuku' bulan musalaha-i umumiyeden sonra bir şahıs, barışmış olduğu husemasından birini ve yahut bir sebeb-i aherle me'murinîn-i hükmetten veya bölükbaşı ve rüesadan birini katl veya cerh ederse o makule eşhas hiçbir vakit afv ve merhamet-i seniyyeye mazhar olamayacaklarından derhal bölükbaşı ve kocabaşı ve kubarlar ma'rifeti ile ta'kib ile derdest ve hükümete teslim ve o gibi eşhası esnay-1 ta'kibde silaha davranırlar ise kubarlar tarafindan mukabele-i bi'l-misil icra olunur. Firar ve ihtifa ettikleri halde haneleri ihrak-1 bi'n-nar olunduktan ve kaffe-i eşcar-1 müsmire ve gayr-i müsmireleri kat've kal' ve arazisi ziraatten ta'til edildikten sonra hiçbir cebelde kabul olunmayıp familyası halkıyla beraber haric-i vilayete tard ve teb'îyd ve kocabaşı ve rüesalar ile kubarların mesarifatına mukabil olmak üzere katillerden altı bin, cârihlerden üçer bin guruş cezay-1 nakdî ahz edilir.

İkinci madde:

Hükümetçe i'lan olunduktan sonra o makule eşhası her kim ki hanesinde kabul ve ihfa ider ise ba'de's- sübut ol hane sahibine katil nazarıyla bakılıp mücazât icra olunacağından başka, kocabaşı ve kubarlar için o gibilerden üç bin guruş ahz ve istîfâ olunur.

\section{Üçüncü madde:}

Bir şahıs esna-yı münaza'ada bir adamı katl ve itlaf ederse makam-ı âli-i vilayetten verilecek emir üzerine bölükbaşı ve rüesalar ile kubarlar derhal katili tutup hükümete teslim edeceklerdir. Katil ita'at edip te hükümete teslim olunur ise mahkeme-i nizamiyeye tevdi' ile hakkında îcâb-1 şer'î ve kanunîsi îfa olunacağı cihetle o gibiler hakkında cibâl usulünce hiçbir muamele icra olunmaz. İta'at etmeyip te firar eyler ise hanesi ihrak olunduktan sonra kocabaşı ve kubarlar içün katilin malından üç bir guruş cezây-1 nakdî istîfầ ve hükümet-i seniyye tarafindan i'lan olunduktan sonra bu gibi katilleri her kim hanesinde kabul ile ihfa ider ise ol hane sahibinden üç bin guruş cezay-i nakdî ahzıyla te'dip olunur.

\section{Dördüncü madde:}

Hukuk-i umumiyye baki kalmak üzre kıtali olan şahsı kocabaşılar vasıtasıyla verese-i maktule hukuk-1 şahsiye namıyla bedel-i sulh i'ta ile da'vadan ferâğat ettirebilir ise de katil ele geçirildiği halde verese-i maktul dava etsin etmesin mahkemece îcâb-1 şer'î ve nazmîsi icra olunur.

\section{Beşinci madde:}

Lede'l-hâce bir tarafa asker sevk olunmak lazım geldiği halde canib-i hükümetten verilecek emir üzerine bölükbaşılar cebellere çıkıp kocabaşı ve alemdar ve cebel ihtiyarları ma'rifeti ile yazılacak asker, sevk olunacak mahalle hitâm-1 maslahata değin îfây-1 hüsn-i hizmet edecek efrâddan birinin veya bir kaçının ma'zeret-i meşrua-i hahikiyyeleri olmaksızın tahrir olunduktan sonra emr olunan mahalle gitmezler ise kocabaşı ve bayrakdar ve kubarlar için her birinden üçer bin guruş cezay-1 nakdî ahz ile beraber cebren mevki'-i harbe sevk edilirler. Tekrar muhalefetleri halinde hanelerinde ne kadar silah-endaz var ise hitam-1 maslahata kadar cümlesi mevki'-i harb-i me'muruna sevk edilir. Bunların dahi muhalefetleri takdirinde meblağ-1 mezbûr ahz ile beraber kaffesi hudud-1 vilayetten tard ve teb'îd edilirler.

\footnotetext{
${ }^{54}$ Bozbora p. 319
} 


\section{Altıncı madde:}

Deyn ve yahud bir sebeb-i âherle bir adamın müteşekkîsi zuhur edipte cânib-i hükümetten celbi lazım gelir ise ol âdem bölükbaşı ma'rifetiyle derhal hükümete getirilecektir. Merkum suret-i muhalefette bulunur ise hükümet-i seniyyeye ita'at etmemiş nazarıyla bakılarak hanesi ihrak ile cebelden tard edilir. Bu gibi eşhâs şayet kocabaşı ve alemdar ve kubarlar tarafindan tesahub olunur ise ol cebelin kocabaşı veya bayrakdar ve ahâlisinden her kim olur ise olsun derdest olunduğu halde istenilen adam gelince veya kendileri hükümete teslim edinceye kadar haps ve tevkif edilirler.

\section{Yedinci madde:}

Evâmir-i hükümeti tebliğ veyahut hükümetten aldığ emir üzerine ba'zı hususâtın tesviye ve müzakeresi zımnında bölükbaşıyla cebele çıkıp kocabaşı ve alemdar ve kubarlar ma'rifetileryle meclis 'akdi îcâb eylediği takdirde meclis-i mezkûra dahil olacak kesandan birinin mâni'-i hakikisi olmadığı halde itâ'at edip gelmez veyahud verilecek kararın hilâfina hareketle maslahatın te'hirine sebebiyet verir ise o halde tecemmu' eden me'murların ziyade te'hir ve tevkiflerine sebep olmuş ve olacağından o makûlelerden zikr olunan me'mûrların masarifâtı için îcâbına göre elli guruşdan beşyüz guruşa kadar ceezây-ı nakdî ahz ve istîfầ edilir.

\section{Sekizinci madde:}

Hükümetin emriyle ve müddeî ve müddê̂-i aleyhin inzimâm-1 re'yiyle bölükbaşı ve rüesâlardan mürekkeb teşekkül edecek komisyonların, hükm hakları olduğu cihetle mezkûr komisyonların bir da'vâya dâir verecekleri hükm ve karar kat'̂̂ olduğundan o misüllü de'âvinin tekrar istimâ'î veyahut başka bir komisyona tevdî'î caiz değildir.

\section{Dokuzuncu madde:}

Verese-i maktûl bi'n-nefs kâtil olan şahıs ile kâtilin hanesinde küçük büyük ne kadar zükûr var ise kâtil nazarıyla bakıp bunlardan kan gütmeğe hakkı vardır. Asıl kâtil olan şahıs vefat eder ise verese-i maktûlün kâtilin hanesi halkından kan aramağa salâhiyeti bâki kalır. Bi’t-tesadüf bunlardan her kangısını katl ider ise ahz-1 sâr etmiş olacağından cezadan ma' füv olur.

\section{Onuncu madde:}

Cebren kız ve karı kaçıran ve fi'l-i şenî icra eden veya bir karıyı darp eyleyen adamdan üçbin guruş cezây-1 nakdî alındıktan sonra karı istirdâd ile sahibine i'âde olunur. Mütecâsir ele geçirildiği halde hükümetçe başkaca te'dîb edilir ise de kaçırılmış kız veya karının müte'allikâtı ikmâl-i nâmus için gâsıb olan şahsı ve onu bulamazlar ise gâsıbın müte'allikâtından birini mutlakâ katl ve itlâf idecek ve fakat ol şahs hükümetçe ve gerek cibâl usulünce kâtil nazarıyla bakılıp hakkında bâlâda zikr olunduğu veçhile mu'âmele olunur.

\section{Onbirinci madde:}

Bir âdem bir hatunu katl ederse kâtilden binbeşyüz ve cerh eyler ise yediyüzelli guruş cezây-1 nakdî alınıp kâtilin hanesi dahî ihrâk olunur.

\section{Onikinci madde:}

Bir kimse diğer kimesnenin bağçesine girerek kasden ızâr veya hayvanâtını sevk ederek zarar ve ziyana ictisâr eyler ise vuku' bulacak zarar ve ziyan bayrakdar ve kocabaşılar ve ihtiyarlar masarıfa(t)1yla keşf olunarak hükm olunacak mikdar iki kat olarak istirdât olunup zarar-dîde olan âdeme verilir. Şayet kasdî olmayıp ta hayvânât çobanın gafletinden dolayı zarar îka' etmişler ise zarar ne ise ol mikdâr hükm ve tahsil olunur.

\section{Onüçüncü madde:}

Bir âdem bir âdemi darp ider ise darbın derecesine göre dâribden binden binbeşyüz guruşa kadar cezây-1 nakdî alınıp mazrûba ve yüzotuziki guruşdan yüzseksensekiz guruşa kadar ihtiyariyye namıyla alınıp rüesâlara verilir. Şayet darp ile beraber silahlarını alır ise üçbin guruş alınıp mazrûba ve üçyüzdoksandört guruş ihtiyariyye resmi rüesâlara verilir.

\section{Ondördüncü Madde:}

Bir âdem cadde-i umûmiyede âhir bir şahıstan cüzî ve küllî bir eşya gasb ederse gasb olunan eşya iki kat olarak aynen veya bedelen istîfâ olunduktan sonra caddenin emniyetini 
selb ettiğinden dolayı gâsıbdan üçbin kuruş cezây-1 nakdî alınıp mağdur olan şahsa ve üçyüzdoksandört guruş dahi başkaca alınıp rüesâlara verilir.

\section{Onbeşinci Madde:}

Bir âdem diğer bir âdemi biçak ile cerh ve katl eder ise bâlâda madde-i mahsûsunda beyan olunduğu vech ile cezâ edilir. Fakat tüfenk ile katl ettikten sonra az ve çok bıçak ile keser veyahut maktûlün hâmil olduğu eslihasından birini veya hepsini ahz eder ise kâtilden altıbin guruş cezây-1 nakdî alıncağından başka verese-i maktûlün kâtilden bir kan ve bir de eslihanın alınmasından veyahut maktûl vurulduktan sonra bıçak ile kesmek gibi hakâret edilmesinden dolayı (birikse) iki kan aramağa hakkı vardır. Fakat nâmus için âdem katl ve itlaf eden şahs cezadan muaf tutulmaz. Şu kadar ki tüfenk ile itlaf olunduktan sonra biçak ile kesilen ve silahları alınan maktûllerin kanları barışdırıldı ğı sırada kâtilden ellibin guruş alınıp maktûlün veresesine ve ihtiyariye olarak yediyüzseksensekiz guruş başkaca alınıp rüesâlara verilir.

\section{Onaltıncı Madde:}

Katl cinayetiyle maznûn olan şahs inde'l-murâfa'a fi'l-i katli inkâr eder ise maktûl olan şahıs hâtun ise kâtil verese-i maktûlün intihab edeceği oniki ve maktûl zükûrdan ise kâtil keza verese-i maktûlün intihab edeceği yirmidört nefer ihtiyârân ile yemin etmeğe mecbûrdur. Kâtil olan şahıs bu suretle yemin eder ise berâet etmiş olur. Yemin etmediği veya edemediği sûrette kâtil nazarı ile bakılıp cezay-1 nakdîsi iki kat olarak istihsal olunacağından başka verese-i mâktûlün bâlâda gösterilen kaide vech ile kendisinden kan aramağa hak kazanmış olur.

\section{Onyedinci Madde:}

Fi'l-i cerh ile maznûn olan şahıs sûret-i inkarda bulunur ise mecruh erkek ise cârih oniki ve mecruh ünâsdan ise cârih altı nefer ihtiyar ile yemin etmeğe mecburdur.

\section{Onsekinci Madde:}

Gece veya gündüz olsun bir âdemin hânesi veyahut mandıra ve ağılını şikest ile eşya sirkat ve gasb etmek o gibi eşya mütecâsirinden iki kat olarak aynen veya bedelen istirdâd ve istîfâ ve hâne ve mandıra ve ağılı şikest etmesinden dolayı dahi beşyüz kuruş cezâ-i nakdî alınıp mağdur olan şahsa verilir.

\section{Ondokuzuncu Madde:}

Onsekizinci maddede beyan olunan eşyay-1 mesrûka bi'l-hisâb herkaç guruşa bâliğ olur ise yüzde onüç guruş on para hesabıyla ihtiyariye masârifi dahi başkaca sârikdan istihsâl olunur. Eşyay-1 mağsûbe hayvânâtdan ma'dûd ise keçi koyun koç kuzu oğlak gibi hayvânâtın kıymeti seviyyen elli guruştan ibaret ise de öküz inek bargir merkep ve eşyay-1 sâirenin fiyatı masraf olmadığından bu misüllü eşya ve hayvânâta erbâb-1 vukûf ma'rifeti ile takdîr olunacak klymetin iki misli istîfâ edilir.

\section{Yirminci Madde:}

Hâne ve mandıra ve ağıl hâricinde sirkat olunan eşya ve hayvânât ve sâire iki kat olarak sârıkdan istirdâd ve bâlâda beyan olunduğu vech ile ihtiyariye istîfâ olunur.

\section{Yirmibirinci Madde:}

Bir sârik madde-i sirkati inkar eder ise mâl-i mesrûkun kıymet ve ehemmiyetine göre sârik ikiden yirmidört nefer ihtiyarlar ile yemin edecektir. Bir sârik veya bir kâtil ve cârih yemin ile berâet ettikten sonra mağdûr olan şahıs şâhid makamında muhbir çıkarır. Ve o muhbir rüesâlardan en mu'temed iki zât ma'rifeti ile hafiyyen hüvviyeti tahkîk ile isticvâb ve istintâk olunduktan sonra ihbârât-1 vâkı'anın sıdk ve sıhhati anlaş1lır ise maznûn olan şahıs mahkûm tutulur.

\section{Yirmiikinci Madde:}

İnde'l-muhâkeme deynini ikrâr eden şahıs mahkûm tutulur. Fakat sûret-i inkârda bulunur ise müdde'i-i aleyh müddeâ bih olan meblağ yüz guruşdan dörtyüz guruşa kadar ise iki ve beşyüz guruştan dokuzyüz guruşa kadar dört ve bin guruş içün sekiz bin dokuzyüze kadar oniki ve ikibin guruştan ikibindoküzyüz guruşa kadar onaltı üç bin guruştan yukarısı için yirmi dört nefer ihtiyarlar ile yemin edecektir. Müddei'-i aleyh olan şahıs bu ta'dâd 
olunan ihtiyarândan ziyade ihtiyar ile yemin etmeğe mecbûr tutulamaz. Bilâ sened mün'akid olan duyûnâtın tarih-i akdinden on seneye kadar rü'yet-i da'va etmez ise on seneden sonra da'vâya selâhiyeti olamaz. Fakat deyn senede müstenid ve merbut ise mürûr-1 zamana i'tibâr olunmayıp medyun deynini inkar eder ise usûlü vechile yemin verdilir.

\section{Yirmiüçüncü Madde:}

İbadet ve icrây-1 âyin etmek 47eyahut vergi tevzi' veya hükümetçe verilen bir emri ahaliye tebliğ etmek üzre cevâmi' ve kilise derûnunda ve havlularında veya câmi' ve kiliseye gider iken âdem urmak ve cerh ve darb etmek mütecâsiri hakkında bâlâda zikr ve ta'dâd olunan cezalardan başka mütecâsirînden beş yüz guruşdan üç bin beş yüz guruşa kadar cezây1 nakdî alınıp câmi' ve kilisenin vakfına îrad kayıd edilir.

\section{Yirmidördüncü Madde:}

Cibâl ahalisinden birinin vefatından sonra arazi ve kâffe-i eşya ve mevâşisi zükûrdan en yakın olan veresesine intikal edip müteveffânın zevce ve kerime ve hemşiresine irsen hiçbir şey isabet etmez ise de bunları te'ehhül etmek ve te'ehhül edinceye kadar idare etmek ve te'ehhül etmek arzusunda bulunmadıkları halde mâ-dâme'l- hayat usulleri vechile idarelerini temin etmek mirasa vâzı'u'l-yed olan adama aiddir.

\section{Yirmibeşinci Madde:}

Bir kız veya karı kendi hüsn-i rızasıyla veyahud ebeveyninin inzimâm-1 re'yi ile bir ademe namzed olmak üzre adetlerince nişan ta'bir ettikleri yüzük veya para vesair bir eşya verilir ise ol karı ve kız başka bir ere varmayacağından mutlaka namzedine varmağa mecburdur. Şayet diğer ere varır ise ol karıyı alan âdem gayrın taht-ı nikâhında bulunmuş olan bir hatunu almış gibi hakkında muamele-i cezâiyye icra edilir.

\section{Yirmialtıncı madde:}

Bir kız âhire namzed olduktan sonra te'ehhül etmesini arzu etmez ise müddet-i ömrünce âhir bir şahıs ile tezevvüc etmeyeceğine dair kız ile kızın ebeveyni mu'teber kefil irae etmeğe mecburdur.

\section{Yirmiyedinci madde:}

Bir şahıs esnay-1 muhakeme ve mürafaada reis ve bölükbaşı ve rüesaya karşı söz söyler veya tahkir ederse derhal muhakemesi ta'til ile ol şahsı cezay-1 nakdî ile ve icabında hapis cezasıyla mahkum edilir. Ve ba'dehu ikame ettiği hukuk davasına bakılır.

\section{Yirmisekizinci madde:}

Bir adam katl kasdiyla bir adama tüfenk endaht ederse ekser cebellerde mütecasirinden beşyüz ve bazı cebellerde bin ve binbeşyüz guruş cezay-1 nakdî alınır.

Reis mevcut iken muavinin komisyonca verilecek re'y ve karalara hakk-1 iştirak ve müdahalesi yok ise de reisin gaybubeti esnasında komisyona riyaset eder. Komisyonun re'y ve müzakeratına müdahale edemez.

\section{APPENDIX 2}

\section{Cibal Komisyonu Maaş Listesi}

Cibal Resi Şakir Bey Maaşı 600, Muavini Hüseyin Efendi maaşı 200, Cibal Katibi Selim Efendi maaşı 188

Cibal reisinin taht-1 riyasetinde olarak merkez vilayetin müteşekkil ve müstahdem ve a'zası rüesay-i cibalden ve dokuz neferden mürekkeb olan Cibal Komisyonu a'zasına Adliye tahsisatı meyanından vilayet mal sandığından kendilerine yevmiye onar kuruş verilir. Ve her ay bi'l-münavebe komisyona devam ederler. Komisyon eyyam-1 ta'tiliyye ve resmiyyeden maada hergün içtima eder.

Hot Cebeli bölükbaşısı Adem Ağa maaşı 350; Gruda Cebeli bölükbaşısı el-Hac Hüseyin Ağa, maaşı 188; Kilmend Cebeli bölükbaşısı Şaban ağa, maaşı 188; Kastrat Cebeli bölükbaşıs1 Abdullah Ağa, maaş1 188; İşkrel Cebeli bölükbaşısı Hüseyin Bey, maaş1 188; Rec maa-Loha Cebeli bölükbaşısı Yusuf ağa, maaşı 188; Repil Cebeli Bölükbaşısı Maaş1 
124; Koplik Cebeli bölükbaşısı Ali ağa, maaşı 124; Gölkenarı Cebeli bölükbaşısı Halil ağa, maaşı 124; Postriba Cebeli bölükbaşısı Muharrem ağa, maaşı 124; Grija Cebeli bölükbaşısı Emin ağa, maaşı 124; Şilak Cebeli bölükbaşısı Abdullah ağa, maaşı 124; Temal Cebeli bölükbaşısı İbrahim ağa, maaşı 12; Şale maa Şoş Cebeli bölükbaşısı Arslan Bey. Maaşı 188

\section{Arşiv Belgeleri}

\section{KAYNAKÇA}

BOA, Y. MTV. 149/81 VRK. 1-8

BOA. BEO $3856 / 289129$ (Hijri) $12 / \mathrm{S} / 1329$

BOA. BEO. 4090/306747, 1330 L 18

BOA. A. DVN. MKL 75/4

BOA. BEO. 3832/287329, 03/Z /1328

BOA. BEO. $3842 / 288080$ (Hijri) 04/M /1329

BOA. BEO. 3842/ 288080 (Hijri) 4/M /132

BOA. BEO. 4087/ 306524

BOA. DH. ŞFR. 302/46 1-5; 9 February 1318

BOA. DH.TMIK.S. $5 / 100$, 07/Ş /1314; 25 January 1897

BOA. İ. DH. $953 / 75381,27 /$ Ş $/ 1302$

BOA. İ. MMS. 48/2028, vrk.3.

BOA. I. Sd 1/7.

BOA. MLV. 977/25 (08/Ş /1280

BOA. MV. 164/68, 1330 Ca 25 / 29 April 1328

BOA. MV. $226 / 113,1330$ S. $22 / 1327$ KS. 29

BOA. ŞD. $311 / 9 ; 22$ July $1886 ; 20 / \mathrm{L} / 1303$

BOA. Y. A. RES. 22 /9; 22 November 1883

\section{Yazma Eserler}

Belediye Yazmaları K 383,vrk. 27 b-40 b

\section{İkinci El Kaynaklar}

Ahmet Cevdet Paşa, Tezakir 13-20, (Cavid Baysun) TTK. Ankara 1960. p. 206

AHMETI, Zef, "The Criminal Law in the "Kanun of Lekë Dukagjini"”,(Tr. Bertan ARIN and Dr Gülsen ALTUNTAŞ) (http://www.shkoder.net/en/kanun_en.htm. ET:01.06.2014)

BALCI, Ramazan, Osmanlı'nın Doğu Siyaseti, Yitik Hazine, İstanbul 2010, p. 30-90 Bedi Nuri, "Müsahabe-i İçtimaiyye, Arnavutluk Teşkilat-1 İçtimaisi: Cibal Kanunu", Şehbal, nr. 64, s. 305, 26 Eylül 1328

BELlO, Hasan, Osmanll Ve Arnavut Kaynaklarina Göre Arnavutluk'ta 1911 Malisörler İsyanl, University of Mimar Sinan Fine Arts. Master Thesis, İstanbul 2009, p. 2.

BOMAN, Sofia and KRASNIQI, Njomza, The Kanun of leke Dukadjini Among Kosova Albanios in Sweden, Malmö University, Department of Global Political Studies, Master's Programme, 2012. P. 45-46 
BOZBORA, Nuray, Osmanlı Yönetiminde Arnavutlar ve Arnavut Ulusçuluğu, Boyut Kitapları, İstanbul 1997

ÇELIK, Bilgin, "Geleneksel Yapı İle Modernite Arasındaki Gerilime Bir Örnek: Arnavutluk'ta Kan Davaları ve II. Meşrutiyet Döneminde Soruna Çözüm Arayışları", Studies of Ottoman Domain, Vol: 4 No:7 August 2014. S 18-41 , Ittihatçılar ve Arnavutlar, II. Meşrutiyet Döneminde Arnavut Ulusçuluğu ve Arnavutluk Sorunu, Büke Yayınları, İstanbul 2004.

DRAGOVAJA, Muharem, A Comparative Study of the Customary Laws Of Mountain Communities in Albania and Dagestan, Tirana 1996.

DURHAM, Edith (1928), Some tribal origins, laws and customs of the Balkans, Illustrated by the author. London: Allen - Unwin, London 1979. 1-318 S.

EGRO, Dritan, Arnavut Topraklarına ait Osmanlı Kanunnameleri Üzerine Sosyo Ekonomik Bir Bakış, The University of Ankara. Master Thesis. Ankara 1997.

EKINCI, Ekrem Buğra, "Osmanlı İdaresinde Adem-i Merkeziyet ve İmtiyazlı Eyâletler", Türk Hukuk Tarihi Araştırmaları, No. 6, Y: 2008 (Fall), p. 7-84. , p. 5.

ERIM, Nihat, Devletlerarası Hukuku ve Siyasi Tarih Metinleri, Ankara 1953, p. 413 and 423.

ERKEN, İlkay, İşkodra Vilayetinin İdari Ve Sosyal Yapısı (1876-1912), Ondokuz Mayıs University. Department of History, Master Thesis, Samsun 2014, p. 427.

Es-Seyyid Mehmed İzzet, Osmanlı Arşivi Belgelerinde Arnavutluk, Devlet Arşivleri Genel Müdürlüğü, Osmanlı Arşivi Daire Başkanlğı, İstanbul 2008 p.203

Kanuni i Lekë Dukagjinit - The Code of Lekë Dukagjini, Albanian text collected and arranged by Shtjefën Gjeçov; translated, with an introduction by Leonard Fox. New York 1989

KOCABAŞOĞLU, Uygur - BIRINCI, Ali, “Osmanlı Vilayet Gazete ve Matbaaları Üzerine Gözlemler”, Kebikeç, No 2, 1995, p. 101-121

KÜLÇE, Süleyman, Osmanlı Tarihinde Arnavutluk, İzmir 1944, p.373

Mustafa Şeref, Hukuk-ı İdare-i Vilâyât, Derseadet 1329, p. 40.

ÖLMEZ, Adem, "Osmanlı Devleti'nin Kosova'da Kan Davalarını Önleme Çalışmaları (1878-1912)”, Güney-Doğu Avrupa Araştırmaları Dergisi, 2009, p. 87-104.

Osmanlı Arşivi Belgelerinde Arnavutluk, Devlet Arşivleri Genel Müdürlüğü Osmanlı Arşivi Daire Başkanlığı, İstanbul 2008.

SAYGILI, Hasip, "20. Yüzyılın Başlangıcından Günümüze Arnavutlarda Osmanlı ve Türkiye Algısı", Bilge Strateji, Vol 6, No 10, Fall 2014 p. 38

SÖYLEMEZ, Banu İşlet, Ittihat Terakki Dönemi Arnavut Muhalefeti ve Arnavut Ulusal Hareketi, İstanbul 2004

SOYYER, A. Yılmaz, Osmanlı Devleti'nde Ilk Alan Araştırması, @kanalkultur İnsan ve Kültüre Dair..29 July 2013 Monday

Vasa Efendi, Arnavutluk ve Arnavutlar, İstanbul Mihran Matbaas1 1298, p. 98-108

YERASIMOS, Stefanos, Azgelişmişlik Sürecinde Türkiye, (Tr. Babür Kuzucu,) vol. I, İstanbul 1987, p.190-191. 